\title{
Naming the dead and the politics of the 'human'
}

\author{
Moya Lloyd* \\ Professor of Political Theory, Loughborough University
}

\begin{abstract}
The summer of 2014 saw several campaigns to name the dead of Gaza. This article aims to explore these initiatives through the idea of the 'human'; understood both in terms of grievability, as a life that matters, and as a 'litigious name' employed by subaltern groups to make political demands. My argument in this article is that politically not all attempts at nomination are equivalent and that a distinction needs to be drawn between those carried out on behalf of the 'ungrievable' and those engaged in by them. Only the latter enables a critical politics of the human potentially capable of transforming the prevailing order of grievability in order to make their lives count. After exploring the interventions that occurred in Gaza in 2014, I turn to how the Western (and Israeli) media represent international deaths to consider what that reveals about the differential valuation of human life. To help make my case I elaborate the idea of an order of grievability. I then explore various attempts by others to name Gaza's dead, and the limitations of their ensuing politics, before finally examining the activities of Humanize Palestine as an example of a more radical, critical politics of the human.
\end{abstract}

\section{Keywords}

Politics of the Human; Naming; Dehumanisation; Grievability; Hierarchies of Death

\section{Introduction}

Throughout July and August of 2014, as numerous media outlets in the UK, US, and elsewhere publicised mortality statistics on a daily basis, it was difficult not to be bombarded with the numbers of those killed and injured in the conflict in Gaza. In conjunction with its televised reports, the BBC ran online features exploring the 'toll of operations in Gaza'. ${ }^{1}$ Israel's oldest daily newspaper, Haaretz, released 'live updates' of fatalities for each numbered day of the crisis, ${ }^{2}$ while The New York Times published both 'The Toll in Gaza and Israel Day by Day' and a daily running total of the dead (both Israeli and Gazan). ${ }^{3}$ Alongside the body counts, however, something else was happening. Sometimes clandestinely, sometimes openly, scribbled on walls or listed in advertisements, occasionally the source of legal wrangling, or the prompt for charitable fund-raising, concerted efforts were under way, particularly on social media, to name the dead of Gaza publically.

* Correspondence to: Moya Lloyd, Department of Politics, History, and International Relations, Loughborough University, Leicestershire, LE11 3TU. Author's email: m.s.lloyd@lboro.ac.uk

1 'Gaza crisis: Toll of operations in Gaza', BBC News, available at: \{http://www.bbc.co.uk/news/world-middleeast-28439404\} accessed 1 February 2015.

2 See, for example, 'Live updates: Operation Protective Edge, day 17', Haaretz (25 July 2014), available at: \{http://www.haaretz.com/news/diplomacy-defense/1.606934\} accessed 10 August 2014.

${ }^{3}$ Karen Yourish and Josh Keller, 'The toll in Gaza and Israel day by day', The New York Times (8 August 2014). 
It is this contestation over the representation of Gaza's dead that I investigate in this article. ${ }^{4} \mathrm{I}$ am interested, in particular, in why naming is regarded as preferable to statistical accounting as a way to record death. I take as my focal point the idea of the 'human'. I have two reasons for this. First, ways of representing the dead (as named individuals or as statistical abstractions) are symptomatic of the workings of what Judith Butler has called grievability, described, by her, as 'a condition of life's emergence and sustenance'. ${ }^{5}$ Grievability links etymologically with grief and, by inference, with death; thus what is often stressed in research on grievability is how the dead are represented, for example, in obituaries, newspaper reports, and the like. But grievability is not a synonym for grief or for death; it is a way to think about liveability. An order of grievability, I argue (and I explicate this concept more fully below) certainly determines how different deaths are hierarchically ranked and how those deaths figure, if at all, in public discourse. But crucially it also governs which lives matter, thus regulating who is deemed fully - that is meaningfully - human, in the specific sense of having a life judged worthy of value, support, and protection. It is this sense of the human, where being human signifies being grievable qua having a life that counts, that I deploy in this article. ${ }^{6}$

Second, the human, I argue, is also a category openly invoked by subaltern groups to make political claims. The term functions as a means to stage a political dispute: to contest specific modalities of exclusion, subordination, or dehumanisation and thereby to enact equality. And Gaza was no exception. One of the initiatives examined in this article, Humanize Palestine, articulates its efforts to name the dead explicitly by way of the human, an idea it summons (invoking the first sense of the human noted above) when it asserts 'that a Palestinian life is no less valuable than the life of another'. ${ }^{7}$ What interests me here is the politics of the human entailed when, in order to make the lives of particular peoples matter, the category of the human is appropriated as, what Jacques Rancière calls, a 'litigious' name. ${ }^{8}$

To do so, I focus on a series of efforts to name the dead of Gaza. My position is that, politically, not all efforts at nomination are equivalent. A distinction needs to be drawn between nominalising actions undertaken by privileged or protected others and those undertaken by subaltern populations. For all the laudable aspirations that might drive the former, such initiatives, I submit, treat humanity

${ }^{4}$ I should, however, make clear from the outset that my focus is not the specifics of the reporting practices of the media in either Israel or the West more generally in respect of Gaza. My interest, rather, is the nature of resistance in this context to particular modes of address (relating to Gaza's dead) as they relate to questions of grievability. For this reason, I do not seek to detail the wider nature of the reporting that took place over the summer of 2014. Nor do I detail how Israeli dead, military or civilian, were represented except to note here that: (a) military deaths were reported by the international media primarily in numerical terms, though the US-based Jewish newspaper Algemeiner named them all. One exception to this was the death of Max Steinberg, an American-Israeli fighting for the Israeli Defence Force. His death was covered by the media in the US, Britain, and Israel; (b) Israeli media routinely named all of Israel's dead, both military and civilian; and (c) outlets in the US and UK reported on and named all four of Israel's civilian dead. For more general discussions of Western media reporting in the region see, for instance, Greg Philo and Mike Berry, More Bad News From Israel (London: Pluto, 2011); and on the Arab media's coverage see Naila Hamdy, 'Arab media adopt citizen journalist to change the dynamics of conflict coverage', Global Media Journal, 1:1 (2010), pp. 3-15; and Lawrence Pintak, 'Gaza: Of media wars and borderless journalism', Arab Media \& Society, 7 (2009), pp. 1-6.

${ }^{5}$ Judith Butler, Frames of War: When is Life Grievable? (London: Verso, 2009), p. 15.

${ }^{6}$ I do not, in other words, offer a substantive definition of the human.

${ }^{7}$ Humanize Palestine, 'About', available at: \{http://humanizepalestine.com/about\} accessed 31 July 2014.

8 Jacques Rancière, 'Who is the subject of the Rights of Man?', The South Atlantic Quarterly, 103:2/3 (2004), p. 304. 
as a status conferred on one party by another; leave unexamined the questions of power and authority at work here; assume a logic of assimilation; and fail to problematise the norm of humanisation in play. In contrast, those activities engaged in by the 'ungrievable' (to borrow Butler's expression) involve a performative politics, in which the ungrievable themselves enact their humanity and grievability by appropriating the very category, the human, from which they are excluded. They do so not in order to demonstrate that they fit an existing (normative) category of the human nor to seek inclusion within an existing order of grievability. Politically, they strive to make themselves count, rather, by disrupting and reconfiguring the prevailing order of grievability, thereby subverting and resignifying what it means to be human.

The article is structured in four parts. In the first part, I return to my opening examples of the conflict in Gaza to consider the nature of these interventions and the purposes they ostensibly serve in naming the dead, drawing attention in particular to the charge that treating Palestinian deaths in statistical terms is dehumanising. Since the 'Western' media, usually referred to generically rather than being specified, sometimes including and sometimes excluding the Israeli press, ${ }^{9}$ was identified by some campaigns as responsible for perpetrating this dehumanisation, in the second part I explore briefly the role of the media in propagating a 'hierarchy of death'. ${ }^{10}$ Useful as this concept is in illuminating the ranking of deaths of different populations, it is not sufficient to capture all that the idea of grievability connotes. So here I elaborate the concept of an order of grievability employed in this article, suggesting how it conditions the representation of Gazan deaths as nameless statistics.

The third and fourth parts of the article return to the efforts to name the dead discussed in part one in order to explore the politics they entail. Part three focuses on the acts of nominalisation carried out on behalf of the people of Gaza, considering both their purpose and their primary audience. I argue that although they attempt to demonstrate that Gazan lives matter and, as such, should not be discounted out of hand, they are nevertheless limited politically in three ways; first, in their focus, which is to alter the perceptions of a specific audience towards the people of Gaza rather than engaging directly with them. Second, they occasion a politics that rests on inequality; one conducted by the relatively secure and privileged towards the vulnerable. Thirdly, that their logic treats humanity as a status granted by one party to another. Not only does this appear to suggest that a life is meaningful only when and if the powerful acknowledge it as such; intentionally or otherwise, it positions subaltern populations as passive victims awaiting the intervention of others.

Part four explores what I am calling a critical politics of the human. This is a performative politics centred on the actions of the ungrievable as they claim grievability, and thus humanity, for themselves. To illustrate what such a politics looks like I explore the activities of Humanize Palestine in both naming the dead of Gaza and in asserting that their lives matter. I am interested in the ways that performatively invoking the name of the human, in such a setting, enables the ungrievable, firstly, to counter their designation as ungrievable as defined within a particular order of grievability and, secondly, to constitute themselves as resistant political subjects.

${ }^{9}$ Although I have serious reservations about referring simply to the 'West' and/or 'Western', because it risks reifying these terms and occluding the foreclosures and erasures that define them, I have elected to do so following the practice of those engaged in the campaigns I am exploring.

${ }^{10}$ Roy Greenslade, 'The Damien Walsh Memorial Lecture', Belfast (4 August 1998), available at (http://cain.ulst. ac.uk/othelem/media/Greenslade.html\} accessed 18 April 2015; see also Roy Greenslade, 'A hierarchy of death', The Guardian (19 April 2007). 


\section{'Once upon a time, they used to have names, and faces' ${ }^{11}$}

Over a three-day period during July, the Tumblr blog 'names on walls' posted photographs of graffiti scrawled by an unnamed Israeli or Israelis on walls in Be'er Shiva, Israel, naming some of the Palestinians killed in the first five days of the Gaza conflict. ${ }^{12}$ That same month, reacting to what it considered to be, 'contrary to the IBA's [Israeli Broadcast Authority] own rules', ${ }^{13}$ the failure of domestic news programmes in Israel to broadcast the names of Palestinian fatalities, Israeli human rights organisation B'Tselem produced its own ninety-second radio advertisement called 'The children of Gaza have a name' offering a 'partial list' of the children killed in the first weeks of the conflict. ${ }^{14} \mathrm{~B}$ 'Tselem's attempts to buy a spot on IBA Radio to air the advertisement were refused on the basis that it was 'politically controversial'. ${ }^{15}$ In response, B'Tselem uploaded the advertisement to Facebook where 'within hours', it claims, it was listened to by 'almost 300,000 people' and 'shared more than 900 times'. ${ }^{16}$

On 28 July, the US-based Jewish Voice for Peace (JVP) and the Institute for Middle East Understanding (IMEU) released a video on YouTube, as part of its Freedom for Palestine: \#GazaNames Project, in which various 'celebrities, artists, and activists' (including American Jews and Palestinians) held up signs with the names and ages of Palestinian dead. ${ }^{17}$ The video and accompanying website encouraged others to 'take action' by submitting 'a photo of how you choose to resist, or the name of the person you want to memorialize'. ${ }^{18}$ In early August, the charity Save the Children placed a full page advertisement in several UK national newspapers entitled 'In Memory of the 373 Children Killed in Gaza 8 July - 3 August 2014' that listed their names. ${ }^{19}$

The summer also saw the launch of two crowdsourcing ventures: the first, Beyond Numbers, describes itself as a 'global initiative powered by a group of youth from around the world, based

11 Asher Schechter, 'When dead children have no names: Israel's terrifying descent into numbness', Haaretz (4 August 2014).

12 'names on walls', available at \{http://namesonwalls.tumblr.com/\} accessed 29 October 2014. The blog also links to lists, in both Hebrew and English, of the names and ages of Palestinians killed over the summer of 2014.

13 Gili Izikovich, 'Israeli agency bans radio clip naming children killed in Gaza', Haaretz (24 July 2014), emphasis added.

${ }^{14}$ Schechter, 'When dead children have no names'. The advert takes its title from a poem about the Holocaust, which declares that 'Every person has a name given to him by God and his parents.'

${ }^{15}$ Hagai El-Ad, 'Newsletter: The Children in Gaza Have Names' (August 2014), available at: \{http://www. btselem.org/btselem-newsletter/144561\} accessed 26 November 2014. See, for instance, Izikovich, 'Israeli agency bans radio clip' and Schechter, 'When dead children have no names'. B'Tselem appealed the decision, but the High Court of Justice found in favour of the IBA stating 'this broadcast means to serve a political purpose and not to simply convey information'. Yehuda Shiezinger and Edna Adato, 'B’Tselem removed from national service volunteer program', Israel Hayom Newsletter (14 August 2014), available at: \{http://www. israelhayom.com/site/newsletter_article.php?id=19453\} accessed 29 October 2014. B'Tselem saw this as an act of censorship, see Izikovich, 'Israeli agency bans radio clip'.

${ }^{16}$ Hagai El-Ad, 'Newsletter'. The advert is available on YouTube at: \{https://www.youtube.com/watch? $\mathrm{v}=\mathrm{qcT}$ ThOabFhg .

17 Jewish Voice for Peace, 'Freedom for Palestine: About', available at: \{http://freedom4palestine.org/about accessed 31 July 2014.

18 Jewish Voice for Peace, 'Freedom for Palestine: Submit a photo', available at: \{http://freedom4palestine.org/ submit\} accessed 31 July 2014.

19 The advertisement appeared on 6 August 2014, by which time a further 35 children had been killed, taking the total to 408 . 
across five continents [sic] (Africa, Asia, Europe, South America, North America)' with a platform 'regularly updated by Palestinians living in the conflict zone'. Sub-titled 'People Beyond Numbers', it aims to remember 'the Victims of Israeli Operation "Protective Edge" on Gaza ${ }^{20}$ by collecting and posting 'the names, images and stories of those [Palestinians] that have lost their lives'. ${ }^{21}$ The second, Humanize Palestine, was a 'community effort' set up in response to the killing, by three Israelis, of Palestinian teenager Mohammad Abu Khedir. ${ }^{22}$ Its online memorials attempt 'to honor the deceased as martyrs by bringing them back to life through their pictures, stories, art, and poetry'. 23

Although all of these interventions were united by their efforts to name the dead, their reasons for doing so differed. The graffiti artist(s) whose activism is documented by 'names on walls' is reported as daubing 'the names in an effort to change the anonymous nature of those killed'. ${ }^{24}$ The rationale behind Save the Children's poster is made clear in the statement from its Chief Executive, Justin Forsyth, which accompanied its launch:

To see the names of the children, some as young as a few months, written in stark black and white brings home the tragedy that has befallen Gaza's children. One child's death is too many; 373 is an outrage that is a stain on the world's conscience. We condemn all indiscriminate attacks on civilians in Gaza and Israel and by publishing these names we are reminding the world of the urgent need to push for a permanent ceasefire. We must ensure that no more young lives are needlessly sacrificed. ${ }^{25}$

The poster was part of the charity's campaign, 'Gaza and Israel Conflict: Stop Killing Children', ${ }^{26}$ calling on the international community to help resolve the conflict in the region on behalf of all its children, Palestinian and Israeli alike. ${ }^{27}$

${ }^{20}$ Beyond Numbers, 'About Us', available at: \{http://www.beyondthenumber.org/about-us/\} accessed 21 October 2014.

21 As well as a crowdsourcing website, Beyond Numbers runs Facebook and Twitter accounts. Beyond Numbers, 'Submit Victim Information', available at: \{http://www.beyondthenumber.org/submit-victim-information/\} accessed 21 October 2014.

22 Ali Abunimah, 'Not just numbers: Online memorial publishes names, faces of Palestinians killed in Gaza', The Electronic Intifada (27 July 2014), available at: \{https://electronicintifada.net/blogs/ali-abunimah/not-justnumbers-online-memorial-publishes-names-faces-palestinians-killed-gaza accessed 7 August 2014. Khedir was a 16-year-old Palestinian, kidnapped and murdered (by beating and burning) by three Israelis (one adult and two youths) in revenge for the murder of three Israeli youths. See fn. 99.

${ }^{23}$ Humanize Palestine, 'About'. Like Beyond Numbers, Humanize Palestine launched a crowdsourcing website, as well as Facebook and Twitter accounts. Two Palestinian-Americans, Bayan Abusneineh and Dana Saifan, established the initiative initially as a way to collect together the names and images of the dead of Gaza being circulated by the 'Palestinian community' during the summer of 2014, though its remit subsequently extended beyond this.

${ }^{24}$ Max Schindler, 'Israelis scrawl the names of the Gaza dead on their city walls', Christian Science Monitor (16 July 2014), available at: \{http://www.csmonitor.com/World/Middle-East/2014/0716/Israelis-scrawl-thenames-of-the-Gaza-dead-on-their-city-walls\} accessed 7 August 2014.

25 Cited in Alice Sharman, 'Save the Children publishes names of 373 children killed in Israel-Gaza Conflict' (8 August 2014), available at: \{http:/www.civilsociety.co.uk/fundraising/indepth/case_studies/content/17965/ campaign_save_the_children_publishes_names_of_373_children_killed_in_israel-gaza_conflict $\}$ accessed 20 April 2015. See also Lizzie Dearden, 'Israel-Gaza Conflict: Names of 373 children killed by bombing released in charity plea for permanent ceasefire', The Independent (6 August 2014).

${ }^{26}$ Sharman, 'Save the Children publishes names'.

27 The campaign also included a petition addressed to the UN Secretary General Ban Ki-moon asking for his intervention. The petition garnered some 80,000 signatures from the public in Britain where Save the Children 
The press release accompanying the launch of the \#GazaNames video described it as part of a political initiative 'speaking out for Palestinian human rights' and expressing 'support for Palestinian freedom, equality and justice' in the face of 'Israel's disproportionate attack on the Palestinian people' in Gaza. ${ }^{28}$ In the words of Rebecca Vilkomerson, executive director of Jewish Voice for Peace, the video offered a 'platform for the growing list of prominent individuals who are outraged by Israel's brutal violence against Gaza's civilian population'. ${ }^{29}$ Similar sentiments lie behind Beyond Numbers. Its efforts to remember 'all innocent victims of the Israeli Operation "Protective Edge" on Gaza' were driven by a desire to 'inspire the world to take action and call for the end of the violence' and by its commitment to 'a free and unoccupied Palestine'. ${ }^{30}$

For all their diversity, one concern was shared by several campaigns. It relates to the 'Western' and Israeli news media's 'routinized reporting' of Gaza's dead as abstractions - 'as $x$ numbers killed and $y$ numbers wounded'. 31 'The mothers, fathers, sons and daughters who've been killed are not numbers ... Each one has a name, an age, a story' announces the voiceover in the \#GazaNames video. Beyond Numbers writes of the need to portray 'a victim and his/her story, rather than as a number to add to the death count'. Explaining why this is necessary, the website authors contend that 'Due to the absence of transparent reporting in the region, news about the fallen is narrowly focused on numbers and often fails to include personal details about those who have lost their lives'. ${ }^{32}$ B'Tselem Executive Director, Hagai El-Ad, reflects similarly on the alleged reluctance of the Israeli media specifically to report 'on the persons killed in Gaza, other than noting the general number of casualties. ${ }^{33}$ B'Tselem is not alone, though, in expressing disquiet about its alleged reluctance of the Israeli media to name names. In an article in Haaretz, journalist Asher Schechter discussing B'Tselem's advertisement, notes that 'Every person has a name, yes, but it turns out not all names are worthy of being read on [Israeli] TV. ${ }^{34}$ '[A]s the list of dead children grew', he notes, in the news 'most remained nameless casualties. Mere statistics, disputed statistics. ${ }^{, 35}$

is based. See more at: \{http://www.savethechildren.org.uk/donate/actions/gaza-and-israel-conflict-stop-killingchildren\#sthash.tKFaAS2U.dpuf\} accessed 20 April 2015 and Save the Children, 'Protecting Children Affected by Conflict', available at: \{http://www.savethechildren.org.uk/get-involved/campaigns/impact/protection\} accessed 5 November 2015.

${ }^{28}$ The video begins with a voiceover that asserts: 'For decades Palestinians have endured statelessness, occupation, dispossession, and a lack of basic rights while Israel has steadily taken their land and denied their freedom.'

${ }^{29}$ Cited in Jewish Voice, 'Freedom for Palestine: About'.

${ }^{30}$ Beyond Numbers, 'About Us'.

${ }^{31}$ Hanan Ashwari, 'Foreword', in Rhoda Ann Kanaaneh, Birthing the Nation: Strategies of Palestinian Women in Israel (Berkeley: University of California Press, 2002), p. xi.

32 Beyond Numbers, 'About Us'.

${ }^{33}$ Hagai El-Ad, 'Newsletter'.

${ }^{34}$ Schechter, 'When dead children have no names'. Schechter suggests that the more children died in the conflict, the less outrage and unease it evoked in the Israeli population. He notes that after four young boys (Ahed Atef Bakr, 10, Zakariya Ahed Bakr, 10, Mohammad Ramiz Bakr, 11, and Ismail Mahmoud Bakr, 9) were killed on 16 July 2014 by Israeli shells when they were playing on a Gaza beach, an event that had something of an impact, the lives of children became 'cheaper'. Their deaths were either greeted, largely, with silence or 'in the most extreme margins of Israeli society' with celebration.

${ }^{35}$ Schechter, 'When dead children have no names'. Although there is not space to develop this point, one of the features of this conflict was the repeated contestation, particularly though not exclusively in the media, of the numbers of those reportedly killed. For a brief overview of this debate see Peter Hart, 'Death in Gaza: Some counts more controversial than others', FAIR (12 August 2014), available at: \{http://fair.org/blog/2014/08/12/ death-in-gaza-some-counts-more-controversial-than-others/\} accessed 19 November 2014. 
The founders of Humanize Palestine, Dana Saifan and Bayan Abusneineh, make parallel claims about the Western media, lamenting its continued reduction of 'Palestinians to numbers'. ${ }^{36}$ Writing about the initiative, Abusneineh expresses concerns that 'Palestinians are portrayed through the media as nothing more than a death toll', ${ }^{37}$ continuing 'We don't know anything about them.' As such, the media constructs Palestinians as persons with 'forgettable names'; 38 aligns 'Palestinian bodies with death and disposability'; ${ }^{39}$ and engages in the "dehumanization and "othering" of Palestinians': ${ }^{40}$ a judgement shared by Beyond Numbers whose website similarly describes Western reporting as 'dehumanizing the Palestinians and their cause'. ${ }^{41}$

In the next section, therefore, I consider briefly what is at stake in Western news coverage of the struggle in Gaza, before setting out what I mean by an order of grievability. My aim here is not to present an in-depth analysis of how the conflict was handled; this article is not primarily an examination of reporting practices of the media ('Western' or Israeli) in relation to Gaza, specifically, or the Middle East, in general. It focuses on the politics of the human entailed by efforts, such as those documented here, to claim grievability for subaltern populations, to make their lives matter, in contexts where they appear not to. Understanding how the media report their deaths is fundamental to understanding how grievability operates in this geopolitical context.

\section{Ordering grievability}

The observation that the deaths of different populations are reported publically in diverse ways is not new. ${ }^{42}$ From at least the late 1990 s onwards, academic commentators have repeatedly pointed to what Roy Greenslade labelled the media's 'hierarchy of death'. ${ }^{43}$ This is a transnational hierarchy in

${ }^{36}$ Humanize Palestine, 'About'. Humanize Palestine's founders do not explicitly define what they mean by the Western media on their website. Comments made elsewhere suggest, however, that this includes, but is not limited to, the Israeli and US news media.

${ }^{37}$ Bayan Abusneineh, 'Reviving our heroes: Challenging Palestinian dehumanization', Mondoweiss (8 August 2014), available at: $\{$ http://mondoweiss.net/2014/08/challenging-palestinian-dehumanization/\} accessed 11 June 2015. Abusneineh makes a very similar point in her interview with Omar Baddar, 'More than a number: Humanising Palestine', The Stream (29 July 2014) available at: \{https://www.youtube.com/watch? $\mathrm{v}=6 \mathrm{QpChZLpmbY \# \}} \mathrm{accessed} 25$ November 2014. Here she notes that 'Palestinians weren't receiving the same amount of coverage ... We didn't know anything about them. Besides, they're reduced to a number, statistics.'

${ }^{38}$ Humanize Palestine, 'About'.

39 Ibid. Of particular concern here is the circulation on social media of images of the corpses of Palestinians at the time of death; in particular, of their 'burned and mutilated bodies'. Since my focus is the mainstream media I do not directly address this issue at this time.

${ }^{40}$ Humanize Palestine, 'Why We Chose "Humanize” Palestine', \{http://humanizepalestine.com/2014/07/29/ why-humanize-palestine/\} accessed 31 July 2014.

41 Beyond Numbers, 'About Us'.

42 There is a growing literature on representations of death in the news media, including William Adams, 'Whose lives count? TV coverage of natural disasters', Journal of Communication, 36:2 (1986), pp. 113-22; Folker Hanusch: 'Publishing the perished: the visibility of foreign death in Australian quality newspapers', Media International Australia, 125 (2007), pp. 29-40; 'Valuing those close to us', Journalism Studies, 9:3 (2008), pp. 341-56; and Representing Death in the News: Journalism, Media and Mortality (Basingstoke: Palgrave Macmillan, 2010); Jonathan Ilan, 'Over a dead body: International coverage of grief', Semiotica, 205 (2015), pp. 229-42; Susan D. Moeller, Compassion Fatigue: How the Media Sell Disease, Famine, War and Death (New York and London: Routledge, 1999); and Terence Wright, 'Collateral coverage: Media images of Afghan refugees 2001', Visual Studies, 19:1 (2004), pp. 97-111.

43 Greenslade, 'The Damien Walsh Memorial Lecture', and 'Hierarchy of death'. See also John Taylor, Body Horror: Photojournalism, Catastrophe and War (Manchester: Manchester University Press 1998), p. 90; 
which (variously) 'foreign deaths always rank below domestic deaths ... deaths at home provide human interest stories that people want to know about, while the deaths of foreigners are merely statistics' ${ }^{44}$ women's deaths count for more than men's, particularly if they are young and white; race and class impact on the volume of reporting; ${ }^{45}$ and deaths in an 'ongoing conflict always receive less coverage than unexpected deaths elsewhere'. ${ }^{46}$ Or, in an alternative geographically-inflected formulation, a 'hierarchy of the dead' where: ${ }^{47}$ 'One dead fireman in Brooklyn is worth five English bobbies, who are worth 50 Arabs, who are worth 500 Africans. ${ }^{48}$

The mainstream media's tendency (in Britain, the US, and Israel) throughout the summer of 2014, therefore, to record Gaza's dead primarily in numerical terms appears to be evidence of just such a hierarchy. Because violent death in the region, particularly amongst Palestinians, is regarded as unexceptional, even normal, the death of a Gazan, unless it is extraordinary or unexpected in some way, is treated as 'just another statistic in an old story with too many tragedies'; a story in this case about non-white, non-'Western' foreigners. ${ }^{49}$

Describing a hierarchy of death, however, is not the same as explaining how it is produced. Hitherto media scholars have tended to point in explanation to factors such as: the proximity (geopolitical, cultural, economic, linguistic, and political) of the death-event in question; the presence or absence of a news desk in a particular location; restrictions placed on reporting by governments or other controlling interests; the 'newsworthiness' of a story; whether the incident is a natural disaster; whether it involves women and/or children; whether it results from violence; the number of tourists affected; as well as other strategic and historical considerations. ${ }^{50}$ I want to pursue a different line of inquiry centred on the human. My contention is that the rank ordering of deaths just alluded to, operationalised via the factors just listed, is indicative of the existence and ongoing operation of, what I am calling, an order of grievability and the norms that configure it.

The notion of an 'order' I borrow from Rancière's idea of the 'police order', which he describes in Disagreement as 'an order of bodies that defines the allocation of ... ways of doing, ways of being, and ways of saying. ${ }^{51}$ This order of bodies is hierarchical and inegalitarian, determining, amongst

Christina Konsantinidou, 'Death, lamentation and the photographic representations of the other during the second Iraq war in Greek newspapers', International Journal of Cultural Studies, 10:2 (2007), pp. 147-66; and Angela Keys et al., 'The political economy of a natural disaster: the Boxing Day Tsunami, 2004', Antipode, 38:2 (2006), pp. 195-204.

${ }^{44}$ Greenslade, 'Hierarchy of death'.

${ }^{45}$ Ibid., and Roy Greenslade, 'Sian murder says a lot about media values', London Evening Standard (30 March 2011).

${ }^{46}$ Greenslade, 'Hierarchy of death'.

${ }^{47}$ Marita Sturken, 'Memorializing absence', in Craig J. Calhoun, Paul Price, and Ashley S. Timmer (eds), Understanding September 11 (New York: New Press, 2002), pp. 374-84.

${ }^{48}$ Cited by Adams, 'Whose lives count?', p. 114, and Moeller, Compassion Fatigue, p. 22.

${ }^{49}$ Greenslade, 'The Damien Walsh Memorial Lecture'. Greenslade's original reference was to Northern Ireland. Arguably there are also other strategies at work in Western media reporting, which structure 'our' perceptions of the conflict in the Middle East and in Gaza specifically, including the discourse of 'human shields' and the highly disputed question of who constitutes a 'civilian'. I do not have the scope in this article to consider them, however.

${ }^{50}$ See, for example, Adams, 'Whose lives count?'; Wright, 'Collateral coverage'; Hanusch, Representing Death in the News; as well as Jack Lule, 'Myth and terror on the editorial page: The New York Times responds to September 11, 2001', Journalism and Mass Communication Quarterly, 79:2 (2002), pp. 275-93.

${ }^{51}$ Jacques Rancière, Disagreement: Politics and Philosophy (Minneapolis: University of Minnesota Press, 1999), p. 29. 
other things, who has a part in society and who does not, whose speech is audible as meaningful speech and whose is not, and what kinds of activity are visible and which are not. I derive the idea of grievability from Butler who develops it as a way to explain the variable value attaching to different lives, where only some warrant security, care, and support. I thus understand grievability as the 'presupposition' for liveable, that is, 'fully human', lives. ${ }^{52}$ Taken together, an order of grievability refers to the hierarchical organisation of who counts as a fully human subject and thus whose lives matter. As Butler surmises in Frames of War, however, the ability to perceive someone as grievable depends on their life being recognisable as a life. Each order of grievability depends, therefore, on 'the normative production of ontology'. 53

To refer to ontology as normatively produced is to construe it as historically contingent and social. It is to argue that ontological claims are, in fact, 'naturalized effect[s] of political configurations' rather than pre-linguistic, pre-given, or natural entities independent of social and political organisation. ${ }^{54}$ Butler demonstrates this clearly in Gender Trouble when she explores how, through the operations of the 'heterosexual matrix', gender naturalises binary sex as an ontological category. As such, an ontology is not a foundation; it is a 'normative injunction' that sets limits to cultural intelligibility, ${ }^{55}$ conditioning what is apprehensible as 'real' and who qualifies as fully human. It is a regulatory and 'regulated domain', operating through norms (of race, gender, corporeal morphology, ethnicity, and so forth), ${ }^{56}$ to produce hierarchical and exclusionary effects privileging certain persons or populations over others. ${ }^{57}$ Ontologies, understood thus, are historically determined and culturally delimited, inseparable from the social and political contexts in which they are embedded, and temporally and spatially particular. They are, furthermore, fully imbricated in power relations.

As regards grievability, the normative production of ontology is visible, for Butler, in the way that certain dead persons, particularly non-Western others (her listings include 'Palestinians', 'Afghan peoples', 'Arab peoples', 'practitioners of Islam', ${ }^{58}$ and 'Iraqis'), ${ }^{59}$ do not qualify for obituaries and or other forms of public recognition by the media. This is because their lives are not apprehended as lives in any meaningful sense. As persons they have no claim on grievability, in other words, because

52 Butler, Frames of War, p. 14.

53 Ibid., p. 3

${ }^{54}$ Athena Athanasiou in Judith Butler and Athena Athanasiou, The Performative in the Political (Cambridge: Polity, 2013), p. 120.

55 Judith Butler, Gender Trouble: Feminism and the Subversion of Identity (London: Routledge, 1990), p. 148.

${ }^{56}$ For consideration of the roles of norms in constituting the fully human, see Judith Butler, Precarious Life: The Powers of Mourning and Violence (London: Verso, 2004) and Undoing Gender (London: Routledge, 2004).

57 Judith Butler, 'How bodies come to matter: an interview with Judith Butler', in Irene Costera Meijer and Baukje Prins (eds), Signs, 23:2 (1998), p. 280. It is also worth noting that in her more recent writings, Butler suggests that ontology also entails 'always being given over to others' (Frames of War, p. 2), an idea central to the account of ethics she advocates. I discuss Butler's ethics further in Moya Lloyd, Judith Butler: From Norms to Politics (Cambridge: Polity 2007); and 'Towards a cultural politics of vulnerability: Precarious lives and ungrievable deaths', in Terrell Carver and Samuel A. Chambers (eds), Precarious Politics: Critical Encounters (London: Routledge, 2008), pp. 92-105. See also the essays in Moya Lloyd (ed.), Butler and Ethics (Edinburgh: Edinburgh University Press, 2015).

58 Butler, Precarious Life, p. 32.

59 Judith Butler, “"Peace is a resistance to the terrible satisfactions of war”: Interview with Judith Butler', in Jill Stauffer (ed.), The Believer, 117:2 (May 2003), pp. 64-72. She contrasts this treatment with the reading out on radio of 'the names of the American soldiers who had been killed' in Iraq. Throughout her post-9/11 work Butler has offered numerous iterations of similar arguments about naming the dead to those mentioned here. 
they do not enjoy ontological status as fully human. ${ }^{60}$ Also, the reason their lives are not (re) cognisable epistemologically as lives is because ontology delimits what counts as 'real'. To categorise a particular population as having a diminished claim to the human is thus to claim that, in terms of the specific ontology in operation, it fails to meet the norms that define what that involves. This means that the 'termination' of lives that are constituted as unreal - are derealised - by normative ontology, as Maja Zehfuss observes, are 'something less than killing'. ${ }^{61}$

When I talk, therefore, of an order of grievability I am not only referring to the kind of comparative ranking of fatalities captured in descriptors such as those noted earlier, hierarchies of death or the dead. I am referring, over and above this, to the particular normative ontology on which a specific distribution of grievability is based, which determines who is fully human (and thus whose lives matter), and to the epistemological entailments that follow on from this ontology. ${ }^{62}$ This includes not only the norms conditioning public discourse (normalising, for instance, how the deaths of certain populations are represented and the language used to describe them) but also those moulding subjects' views of the world, framing what it is possible for them to see, to hear, and to say: which violent deaths, for instance, are visible as violent and which are not, whose appeals for support are audible as appeals for support and whose are not, and whose deaths might be spoken about publically and whose not.

So far, this article has discussed orders of grievability largely in the singular. However, care needs to be taken here. In her discussion of 'hierarchies of grief', ${ }^{63}$ Zehfuss quite rightly takes issue with Butler's overly simplistic division between 'highly protected Western lives' and 'disposable nonWestern lives' (or rather 'non-Western non-lives'). She demonstrates that what Butler presents as a 'general truth' - that non-Western lives are ungrievable - is, actually, a 'point about public discourse in the United States, or perhaps in the West more broadly' ${ }^{64}$ Zehfuss also criticises Butler's failure to acknowledge that, in fact, even in the terms of Western public discourse, the very populations Butler alleges are ungrievable are sometimes grieved. Here Zehfuss draws attention to the work of organisations such as Iraq Body Count in publicising the deaths of so-called 'ungrievable' non-Western populations. ${ }^{65}$ Finally, she adds to Butler's account by exploring, what she refers to as, 'an intriguing omission' from the latter's discussions: the existence of a particular set of grievable Western lives

${ }^{60}$ In fact, for Butler, the constitution of the human (subject) involves the simultaneous constitution of what she refers to in Bodies That Matter: On the Discursive Limits of 'Sex' (London: Routledge, 1993) as a domain of the 'more or less "human", the inhuman, the humanly unthinkable', p. 8; see also Butler, Undoing Gender, pp. 24-5. As such, 'dehumanization', for her, is 'the condition for the production of the human', Butler, Precarious Life, p. 91. Understood thus, dehumanisation does not refer to practices directed at those already constituted as human, as is more conventionally assumed. It is part of the process through which the human is produced. In this, dehumanisation parallels Butler's earlier discussion of abjection; see Lloyd, Judith Butler, pp. 74-6. See also Drew Walker, 'Two regimes of the human: Butler and the politics of mattering', in Lloyd (ed.), Butler and Ethics, pp. 141-66.

${ }^{61}$ Maja Zehfuss, 'Hierarchies of grief and the possibility of war: Remembering UK fatalities in Iraq', Millennium, 38:2 (2009), p. 421. The fact, as Butler puts it, that the media fails to name or show the dead means that normatively 'there never was a life, and there never was a death' (Butler, Precarious Life, p. 146); the effect of which is to annul any violence committed against such persons.

${ }^{62}$ Specifically, the latter encompasses what Butler refers to as 'the epistemological problem of apprehending a life' consequent on the normative production of ontology (Frames of War, p. 3).

${ }^{63}$ The expression 'hierarchy of grief' in the singular is Butler's; see Butler Precarious Life, p. 32.

${ }^{64}$ Zehfuss, 'Hierarchies of grief', p. 423.

${ }^{65}$ See also Maja Zehfuss, 'Subjectivity and vulnerability: On the war with Iraq', International Politics, 44 (2007), pp. $58-71$. 
whose deaths (like those of the ungrievable) are 'accepted as a matter of course', namely those of the armed forces. ${ }^{66}$

What criticisms such as Zehfuss's reveal is that it does not make sense to talk of grievability simpliciter; a particular population is only grievable (or ungrievable) within a specific order of grievability. This is true of the Palestinian populations that are my concern in this article. They are not ungrievable, per se. In fact, many of their deaths were reported, by broadcasters such as Al Jazeera, Al Arabiya News, and Al-Alam, in newspapers such as Al-Akhbar, or announced on radio by, for instance, the Ajyal Radio Network, where they were mourned (and I will return to this later) as singular, irreplaceable, individuals, whose lives mattered. Rather they are ungrievable within the particular order reflected in and perpetuated by the mainstream Western (including Israeli) media, where their deaths, if they figure at all, are chronicled en masse, anonymously and arithmetically. For this reason, it is important to be aware that, globally, at any one time, plural orders of grievability exist.

There are three final points to note about orders of grievability. First, while within any particular order a broad distinction will exist between those who are grievable and those who are not, gradations exist. There will be lives that matter more than others amongst the grievable, as Zehfuss has shown, and lives that matter even less amongst the ungrievable, African lives compared to Arab lives to recall Moeller's observation. Moreover, the division is not fixed once and for all. Depending on circumstances, a different ranking might prevail; for example, in some conditions a heteronormative hierarchy placing heterosexual lives as more valuable than gay, lesbian, or transsexual lives might preponderate. In another situation, civilian lives might be regarded as more valuable than military lives. Or, as in the discussion at hand, the issue might have transnational implications, as when non-'Western' lives count for less than 'Western' lives.

Next, orders of grievability depend for their continued functioning on what Foucault calls diverse 'forms for transmission and diffusion', ${ }^{67}$ including reiteration through mechanisms such as public policy (foreign and domestic), the 'social and political organizations that have developed historically to maximize precariousness for some and minimize precariousness for others, ${ }^{68}$ and/or the kinds of media discourse relevant here. This latter point is important. My claim in this article is not that the media originate or generate hierarchies of death ab initio; the media is simply one of the mechanisms through which norms of grievability circulate and are reiterated. Lastly, while ordering grievability is almost certainly inevitable in any society, no order is natural or inexorable; all are historically and culturally contingent. Because of which, and this is important to my discussion later on, any determinate order has the potential to be contested; to be interrupted, disrupted, or even reconfigured.

So far in this section, I have identified the kinds of hierarchy discernible in media coverage of violent death pertinent to the context at hand, have argued that they are symptomatic of the workings of a

66 Zehfuss, 'Hierarchies of grief', p. 424. It might, of course, be possible to complicate further Zehfuss's own analysis of military deaths by exploring the ways in which they too might be differentially ranked, along the lines for instance of the analysis offered by Yagil Levy in Israel's Death Hierarchy: Casualty Aversion in a Militarized Democracy (New York: New York University Press, 2012).

${ }^{67}$ Michel Foucault, 'History of systems of thought', Language, Counter-Memory, Practice: Selected Essays and Interviews, ed. Donald F. Bouchard (New York: Cornell University Press, 1980), p. 200.

${ }^{68}$ Butler, Frames of War, pp. 2-3. 
particular order of grievability, and have defined what I mean by that term. I have also intimated that multiple, intersecting norms of humanisation (including those of gender, sex, ethnicity, and race) are at play in the production of lives that matter - grievable lives. There is, of course, one other factor that is relevant: in the Western media's reporting of death 'humans' have names while, according to Beyond Numbers and Humanize Palestine, those who have been dehumanised do not. They are treated as brute statistics. What interests me is how their 'dehumanization' through de-nomination might be countered; specifically, how 'those of no account' (to borrow Rancière's phrase) might come to count. ${ }^{69}$ At this juncture, therefore, I return to the initiatives discussed at the beginning of the article to consider the politics of the human discernible in their nominating activities. Here I will explore the distinction set out in my introduction between political interventions carried out on behalf of the ungrievable and those directly involving them.

\section{Naming the unnamed}

If failing to name the dead is dehumanising, then it might reasonably be assumed that to name them is to humanise them, to make their lives matter. Reflecting on Chilean artist Alfredo Jaar's The Rwanda Project, ${ }^{70}$ for instance, Jacques Rancière pinpoints the power of visual art to 'make seen what cannot be seen', ${ }^{71}$ observing:

What is not visible, what had to be made visible, was that the victims of this mass murder were all individuals. They had to be given their name, an inscription in the order of discourse and memorial, because indifference to those deaths in fact prolongs a certain invisibility, the feeling that these lives are external to the world of discourse. ${ }^{72}$

What concerns Rancière (here and elsewhere) is 'indifference'; indifference towards the fate of 'those living beings who already did not affect us, individuals whose names were meaningless to us' ${ }^{73}$ It is precisely to sensitise us to their stories and to redistribute 'the way we count', as he puts it, that their 'names have to be made visible'. ${ }^{74}$ Likewise Butler's speculation about what happens 'when we attempt to name, and so bring under the rubric of the "human"' those 'we are asked not to mourn', ${ }^{75}$ would appear to suggest that publically naming the dead is an appropriate political means to surmount the problem of their namelessness and invisibility. Indeed, she provides further support for this position when she observes how the 'utterance of a name can come as the most extraordinary form of recognition, especially when one has become nameless'. ${ }^{76}$ As regards the politics of the

${ }^{69}$ Rancière, Disagreement, p. 36.

${ }^{70}$ This is a series of 21 pieces, produced between 1994 and 1998, representing the Rwandan genocide and motivated by Jaar's outrage at the 'international community's reaction - the barbaric indifference' to the crisis. Jaar in 'Alfredo Jaar: "The Rwanda Project”, an interview', art21, available at: \{http://www.art21.org/texts/ alfredo-jaar/interview-alfredo-jaar-the-rwanda-project\}, accessed 28 May 2015.

${ }^{71}$ Jacques Rancière in Marie-Aude Baronian and Mireille Rosello, 'Jacques Rancière and indisciplinarity: Interview', Art and Research, 2:1 (2008), p. 8.

72 Ibid., emphasis added.

73 Jacques Rancière in Baronian and Rosello, 'Theater of images/Le théatre des images', in Nicole Schweizer (ed.), Politics of the Image/La Politique des Image/ (Lausanne: JRP/Ringier, 2007), p. 75; see also Rancière in Baronian and Rosello, 'Jacques Rancière and indisciplinarity'.

${ }^{74}$ Rancière, 'Theater of images', p. 75. This includes the names of the dead, the living victims of the Rwandan genocide, and killing sites.

75 Butler, Precarious Life, p. 46, emphasis added. She is referring here to those killed by US and allied forces. See also Erica Doss, Memorial Mania: Public Feeling in America (Chicago: University of Chicago Press, 2007), p. 112.

${ }^{76}$ Judith Butler, 'Can one lead a good life in a bad life? Adorno Prize Lecture', Radical Philosophy, 176 (2012), p. 12. 
human, however, a distinction needs to be drawn in my view between nominalising acts carried out by the emplaced on behalf of a particular population, or some subset thereof, and those orchestrated or actively engaged in by subaltern populations themselves. ${ }^{77}$ There are three reasons for this.

First, the primary goal of many of the interventions previously detailed was to change the consciousness of a particular population (British, Israeli, American, or 'Western') towards the plight of the people of Gaza rather than acknowledging the humanity of the latter directly. The Israeli human rights organisation, B'Tselem, for instance, sought to challenge the failure - or refusal - of the IBA to broadcast the names of Palestinians killed in Gaza by producing its own advertisement in Hebrew; thus endeavouring to draw to the attention of the Israeli public what had, in its view, been 'effectively silenced and erased from the public sphere', a 'human issue of utmost, urgent political importance'. ${ }^{78}$ Similarly, the graffitiing of names of Palestinian dead on the walls of Be'er Shiva was directed foremost at its inhabitants, predominantly Jewish, in an effort, as one Israeli journalist wrote, to 'remind ... us of what we really want to forget' ${ }^{79}$ Save the Children's poster originally appeared in British daily newspapers: The Independent, the $i$, The Times, The Guardian, and The Telegraph. It was devised, as a spokeswoman for the British-based charity notes 'to keep the children who have suffered in this war at the forefront of everyone's mind', 80 the 'everyone' in question being presumably members of the British public. ${ }^{81}$

Even so, we might still want to argue that despite their diversity, all of these efforts to name the dead are committed to the idea that Gazan lives matter; that they are - or ought to be - grievable. The trouble however, and this is my second concern, is that when such humanising efforts are practised in conditions of inequality, where inegalitarian power relations prevail as they do in the present context, as Didier Fassin notes, what follows is a 'politics of inequality', 'directed from above to below, from the more powerful to the weaker, the more fragile, the more vulnerable' ${ }^{82}$ This is a politics that rests on the same asymmetrical 'relation of domination' that facilitates the discounting of the lives of the latter in the first place. ${ }^{83}$ Understood thus, humanness-qua-grievability is treated as a status, even a gift, bestowed by the already-human (the geopolitically privileged) on and received by the not-yet-human (populations in positions of heightened vulnerability, insecurity, and precarity). This has two effects. It implies that a life is meaningful only when the already human, the emplaced or the privileged, declare it to be. This is particularly problematic where the West is

${ }^{77}$ The term 'emplaced' derives from Mark Franke, 'The unbearable rightfulness of being human: Citizenship, displacement, and the right to not have rights', Citizenship Studies, 15:1 (2011), pp. 39-56. Strictly speaking, of course, the dead can never speak for themselves, so all naming is, in some sense, done by others. However, it is not just Gaza's dead who, in Butler's formulation, are ungrievable, so too are the living Palestinians of the region, who also do not fit the normative conception of the human. So, when I talk of subaltern populations acting on their own behalf, I am including the living.

${ }^{78}$ B'Tselem, 'Press Release: IBA Censors B'Tselem Radio Spot Listing Names of Gazan Children Killed' available at: \{http://www.btselem.org/press_releases/20140721_children_killed_in_gaza_have_names\} accessed 26 November 2014.

79 'Memorial Wall', available at: \{http://www.ha-makom.co.il/gallery/names-on-walls\} accessed 5 November 2015 , translated. This news site dubbed the graffiti the 'memorial wall'.

${ }^{80}$ Cited in Sharman, 'Save the Children'.

${ }^{81}$ Although I do not have scope here to elaborate on this at this time, all of these initiatives ultimately reached a wider audience than those for whom they were initially intended, primarily through their dissemination via social media.

${ }^{82}$ Didier Fassin, Humanitarian Reason: A Moral History of the Present (Berkeley and Los Angeles: University of California Press, 2012), pp. 3-4.

${ }^{83}$ Ibid., p. 3. 
involved; for as critics such as Mark Franke, Sunera Thobani and others have shown, it risks perpetuating a particular racial and imperialist dynamic. ${ }^{84}$ It also presents subaltern populations as passively awaiting admittance to the category of the human and not as resistive political actors asserting humanity in their own right.

Thirdly, although nominalising initiatives such as those undertaken by \#GazaNames, B’Tselem, and others, might help temporarily to reorder a specific hierarchy of death, such that Palestinian lives are recast as more worthy than they once were, in and of themselves, they do little to contest the norms by which the human (the life that matters) is defined and, thus, to trouble the reigning order of grievability. They do not, for example, interrogate the privilege attaching to the lives that matter (white Western lives, for instance), problematise the specific mechanisms through which naming as a norm of humanisation takes place, or query which particular institutions or organs within that order are authorised to bestow or refuse grievability on others. ${ }^{85}$ In this sense, they extend, rather than subject to critique, existing indices of grievability and humanising norms, with the effect that subaltern populations are simply incorporated within and assimilated to the existing order of grievability when the powerful deign they might be. ${ }^{86}$

\section{Towards a critical politics of the human}

In the final part of this article, therefore, I want to explore the politics of the human in what might be called its critical mode by focusing on what happens when the ungrievable themselves assert their humanity. In particular, I am interested in how such an assertion might potentially lead to a reconfiguration of the order of grievability. My argument in what follows is that, provisionally, a politics of the human is more likely to have transformative effects, firstly, when it involves, what Fiona Jenkins in a different context aptly calls, 'an event of contestation, ${ }^{87}$ leading to what Butler suggestively describes as 'an insurrection at the level of ontology'. ${ }^{88} \mathrm{~A}$ critical politics of the human, in other words, will be one that puts into question the sphere of appearance of the human; that is, our sense of 'reality' and the 'normal'. It will seek to rupture the normative ontology, in other words, that disallows the ungrievable ontological status as human. Next, unlike the appeals, discussed in the previous section, that petition another, in this case the media, to name those whom it does not routinely name, to humanise them that is, a critical politics will enact that humanity directly. It will arrogate to itself the authority to determine that subaltern lives matter. Lastly, a critical politics of the human, as already hinted, will involve resistive, political actions by the ungrievable themselves. It will rest on their performative assertion of their own humanity.

${ }^{84}$ Franke, 'The unbearable rightfulness of being human'; Sunera Thobani, 'White wars: Western feminisms and the "War on Terror"', Feminist Theory, 8:2 (2007), p. 177. See also Thomas Gregory, 'Potential lives, impossible deaths', International Feminist Journal of Politics, 14:3 (September 2012), p. 335; Walker, 'Two regimes of the human', p. 145.

${ }^{85}$ For instance, while some of them engaged in criticism of a specific media for failing to name the dead of Gaza, they did not problematise the fact that the media (amongst other bodies) is authorised to do so in the first place. They simply accept as given that it has this role.

${ }^{86}$ See also Butler, Precarious Life, p. 33; Moya Lloyd, '(Women's) human rights: Paradoxes and possibilities', Review of International Studies, 33:1 (2007), pp. 91-103; Franke, 'The unbearable rightfulness of being human'.

${ }^{87}$ Fiona Jenkins, 'Sensate democracy and grievable life', in Lloyd (ed.), Butler and Ethics, p. 123, emphasis in original.

${ }^{88}$ Butler, Precarious Life, p. 33. 
As the earlier exploration of orders of grievability revealed, the ability to see others as grievable is shaped and consolidated by socially articulated and historically variable norms that constitute only some persons as fully human and thus visible within a given order of grievability. The dehumanisation of those excluded ontologically from that order means they are neither perceptible nor apprehensible as normatively human, thus their lives are of no particular account. This is what renders them ungrievable. In order to claim grievability, therefore, ungrievable populations or persons need somehow to make themselves visible, audible, and thus apprehensible as human. One way to do this, I propose, is by invoking 'the human', as what Rancière calls, a 'litigious name'; 89 a name that serves, as I will show, to allow the ungrievable, in this context, to performatively enact their humanity. Before I turn to Humanize Palestine to illustrate my argument, I need first to explain what Rancière means by this locution. To do so it is necessary to turn, briefly, to his distinctive understanding of politics.

Police, as noted earlier, is Rancière's label for the distribution of roles and parts in society; how, in other words, it is organised. Operating through mechanisms such as policy, law, judicial decisions, as well as economic arrangements and cultural phenomena, the police order establishes particular modes of doing, being, and communicating. ${ }^{90}$ It thus structures reality - and it does so in hierarchical ways. Where police ranks persons, modes of knowledge and so on, politics for Rancière, by contrast, is inherently egalitarian and democratic, resting on what he refers to as the 'equality of any speaking being with any other speaking being, ${ }^{91}$ It begins with the staging of a 'wrong'. This occurs when a part of society not acknowledged as being equal within the existing police order acts as if it is so; when, that is, the 'uncounted' (or the demos, for Rancière) 'practices', or implements, equality. ${ }^{92}$ When that happens bodies shift from their allocated places and the hierarchical police order is disrupted; it is denaturalised and so revealed as contingent. Rancière thus equates politics with 'dissensus', his concept for the ways in which subaltern groups contest and reject, as Todd May puts it, 'the position or positions its members have been allotted' within a given police order. ${ }^{93}$

This is where the idea of litigious names becomes pertinent. Litigious names, and Rancière includes 'human being' amongst them, ${ }^{94}$ are 'political names' that 'set out a question or a dispute

${ }^{89}$ Rancière, 'Who is the subject of the Rights of Man?', p. 304; see also Jacques Rancière, 'Politics, identification, and subjectivization', October, 61 (1992), pp. 58-64.

${ }^{90}$ Samuel A. Chambers, 'Police and oligarchy', in Jean-Philippe Deranty (ed.), Jacques Rancière: Key Concepts (Durham: Acumen, 2010), p. 61. For further discussion, see, for example, Samuel A. Chambers, The Lessons of Rancière (New York: Oxford University Press, 2013); Deranty, Jacques Rancière; Todd May, The Political Thought of Jacques Rancière: Creating Equality (Edinburgh: Edinburgh University Press, 2008); and Joseph J. Tanke, Jacques Rancière: Politics, Philosophy, Aesthetics (London: Continuum, 2011).

${ }^{91}$ Rancière, Disagreement, p. 30.

${ }^{92}$ Equality as Rancière thus understands it is not something granted, distributed, or protected by the state via, for instance, rights or the law. It is not, as he puts it, 'an essence embodied in the law or a goal politics sets itself the task of attaining' (Rancière, Disagreement, p. 33). It is 'not given, nor is it claimed'. Equality, by contrast, is 'practiced', or what Rancière calls 'verified'. See Jacques Rancière, The Ignorant Schoolmaster: Five Lessons in Intellectual Emancipation (Stanford: Stanford University Press, 1991), p. 137, emphasis in original. Equality is, in other words, performed by subaltern groups when they act politically; when, that is, they act as if they have the equality previously denied through the organisation of the social. In the context under discussion, this suggests that the granting by others of 'equality' or humanity to the displaced, dispossessed, and so forth is a 'police' response; one that, ultimately, sustains that order. On Rancière's view of equality, see May, The Political Thought of Jacques Rancière.

${ }^{93}$ May, The Political Thought of Jacques Rancière, p. 49.

${ }^{94}$ Rancière, 'Politics, identification, and subjectivization', p. 60. 
(litige) about who is included in their count'. ${ }^{95}$ They are names that politicise the distinction, therefore, between those encompassed by general appellations such as man, citizen, human, and those who are not. As part of a process Rancière describes as 'subjectivization', employing political names not only enables those acting politically to dis-identify from, that is to reject, their policed identities, capacities, and roles; it also facilitates the constitution of new (collective) resistive subjects, ones not formerly possible within the police order in contention. ${ }^{96}$ Subjects that become visible, in other words, through politics. Litigious names serve, then, as Joseph Tanke writes, both as 'a means for resisting hierarchy' and contesting inequality and for reordering 'what is perceivable, thinkable, and possible'. ${ }^{97}$

It is my suggestion in this article that we understand the actions of Humanize Palestine in these terms. That is, as utilising the name of the 'human' litigiously in order to challenge how grievability, and thus humanness, are allocated within the prevailing ('Western') order of grievability, by politicising the distinction between whose lives count and whose do not.

On its website, an explanation is offered as to why the name Humanize Palestine was selected. The reason was not, it states, 'to suggest that Palestinians are not human already or that Palestinians need to prove their humanity' but rather 'to challenge [sic] Western media's dehumanization and "othering” of Palestinians'. ${ }^{98}$ From a (loosely) Rancièrian perspective, we might understand this statement as identifying a wrong. Asserting that Palestinians are already human yet, paradoxically, in need of humanisation does two things. Firstly, it enacts the equality of a population not presently enjoying ontological status as human; one that is not (yet) apprehensible as such. Secondly, it points explicitly to the inegalitarianism at the heart of the prevailing order of grievability. This is the inegalitarianism reiterated by the Western media when it employs fatality metrics to represent Palestine's dead. Furthermore, when, through its website and social media activities, Humanize Palestine honours Gaza's dead and refuses the representations of them circulating in the mainstream Western media, it expresses a dissensus, by defying the order that positions Palestinians as less than human.

Recall that within the transnational order of grievability under scrutiny, it is alleged that the representation of Palestinians as nameless statistics dehumanises them and validates their corporeal expendability. As Humanize Palestine's founders indicate, this is in stark contrast to how Israeli deaths are reported. Pointing to the case of the three Israeli teenagers (Naftali Fraenkel, Gilad Shaer, and Eyal Yifrah), who went missing in June $2014,{ }^{99}$ one of them notes, their 'names, ages and pictures' were all over the news. ${ }^{100}$ 'We knew what they looked like, who their families were and

95 Rancière, 'Who is the subject of the Rights of Man?', p. 303, emphasis added. In Rancière's idiom these occasions entail 'miscounts', ways of inscribing the 'uncounted in a space where they are countable as uncounted', see Rancière, Disagreement, pp. 38-9. See also Andrew Schaap, 'Enacting the right to have rights: Jacques Rancière's critique of Hannah Arendt', European Journal of Political Theory, 10:1 (2011), p. 36.

96 See Rancière, Disagreement. The point about these new subjectivities is that they are not policed identities but the mechanism for evading those identities. See Tanke, Jacques Rancière, p. 67.

97 Tanke, Jacques Rancière, p. 21.

${ }^{98}$ Humanize Palestine, 'Why We Chose', emphasis added.

99 The three boys in question, two aged 16 and one aged 19 (Yifrah) were kidnapped from the West Bank and murdered, allegedly, by two members of the al-Qassam brigades, the armed wing of Hamas. Their murder was one of the triggers for the conflict in the summer of 2014.

100 This is certainly borne about by a brief examination of the new media. In the US, The New York Times, New York Daily News, The Washington Post, Los Angelos Times, CNN, CBS, and Fox News all carried stories of 
whether they were good in school or not.'101 'Images of them', she comments, 'smiling and posing with their families circulated. ${ }^{102}$

We might understand this objection thus: that the media's classification of Palestinians in numerical terms produces them as an undifferentiated, anonymous mass by representing them as victims without personal histories or individuality. Conversely, Israelis are treated, to borrow from Jenny Edkins, as 'persons-as-such': ${ }^{103}$ that is, as unique, irreplaceable, individuals, subjects whose experiences of life, death, and suffering are quite unlike those of anyone else, whose hopes, dreams, and aspirations are particular to them, and who as persons exist within exclusive familial, communal and friendship relations. To counter this differential treatment, and to demonstrate the value, singularity, and humanity of Palestinian lives, therefore, the vignettes, or mini-obituaries, posted on Humanize Palestine's various social media sites not only name each of Gaza's dead; they share personalised stories about them, usually accompanied by either informal snapshots or formal photographs of the dead in life, as well as occasional videos by or about them. ${ }^{104}$

Accordingly, we learn that brothers Anas and Sa'ad Akram al-Skafi, for instance, scored 88 and 91 per cent respectively in the general secondary examination, the Tawjihi; that Yousef Jameen Sheikh al-Eid was a 'nurse', Hani Mohammad al-Hallaq a 'web developer', Abdullah Nasr Fahjan a 'sports journalist', Atef Salih Alzamli an on-duty 'paramedic'; that twelve-year-old 'shy performer' Sha'ban Jameel Ziada, 'loved to sing', six-year-old Kenan Hassan al-Hallaq 'loved solving puzzles', and his pregnant mother Samar Osama al-Hallaq, 'was involved with the Palestinian History Tapestry Project'; and that nine-year-old Ali Sha'baib ash-Shinbari was hoping to be a lawyer while footballer Abdelrahman Jamal al-Zamli was intending to marry. ${ }^{105}$

their abduction and death, as did the BBC, ITV News, The Guardian, The Telegraph, and Daily Mail in the UK, as well as, further afield, The Irish Times, Al Jazeera, Le Monde, and Le Figaro. Once their names were released by the Israeli state, news reports routinely contained biographical information about them (minimally their names and ages), as well as their photographs. Some offered more detailed portraits covering their main characteristics and hobbies, as well including comments by friends and family

${ }^{101}$ Abusneineh, 'Reviving our heroes'.

${ }^{102}$ Abusneineh in Baddar, 'More than a number'.

103 Jenny Edkins, Missing: Persons and Politics (Ithaca; London: Cornell University Press, 2011). Edkins, however, does not connect the person-as-such with the human.

${ }^{104}$ In some cases, the images take the form of 'martyr's posters'. Normally, these posters, found in the local community and addressed to them, include 'a photograph of the martyr', some form of text, usually taken from the Koran, various symbols, all enclosed within a decorative border. Their purpose is to enable Palestinians to represent themselves 'as courageous heroes rather than victims'. For more on this topic see Mahmoud Abu Hashhash, 'On the visual representation of martyrdom in Palestine', Third Text, 20:3-4 (2006), pp. 392-3. The stress on resistance was also emphasised by Humanize Palestine in seeking to highlight 'daily acts' of resistance by Palestinians against their plight in order to problematise the construction of their lives as defined exclusively by 'oppression, massacres and occupation' (Humanize Palestine, 'Why We Chose'). One way it does so is by recording whom amongst the dead were involved in conventional resistance, as say fighters in the al-Qassam brigades.

105 All the cited examples are taken from Humanize Palestine, 'In Memory: Attack on Gaza July 8-August 26 2014', available at: \{http://humanizepalestine.com/category/gaza-2014\} accessed 3 February 2016. It is worth noting that its Facebook page takes a similar format to the website, replicating much of the information about the initiative featured there, and includes the album 'The Faces \& Stories of Palestine', while its Twitter account also posts images and stories of the deceased. In addition, a booklet commemorating those killed during the summer of 2014 is available at: $\{$ https://issuu.com/humanizepalestine/docs/hp_booklet\}, accessed 15 March 2016. 
In terms of the critical politics of the human I sketched earlier, representing Palestinians like this allows Humanize Palestine to rupture the social ontology that initially disallows them human status, by making visible what the prevailing order sought to efface: their uniqueness and inimitability as persons. Operating through the litigious name of the human Palestinians are thus performatively constituted as fully human, as grievable beings whose lives matter. It is not that the human as a category is now identified definitively with a remodelled version that newly incorporates Palestinians within it. The human, on this interpretation, does not denote a particular subject, identity, or collective body that could be extended in this way in order to include those outside its remit. ${ }^{106}$ The purpose of Humanize Palestine's intervention is not, then, to demand that Palestinians be treated like Israelis, or to claim they ought to occupy a similar position to them in the prevailing order of grievability. It is better understood as a rejection of, an insurrection against, the ontology that positions Palestinians as less-than-human. It is a repudiation of the order of grievability that classifies them as ungrievable; an effort to reconfigure what it means to be human, in the sense of having a life that counts.

Moreover, as a critical politics, Humanize Palestine does not address itself to or directly call on the Western media to acknowledge Gazan grievability. It does not petition those already deemed human to recognise those denied that status or to acknowledge that their lives also count. In effect, it refuses the notion that the power to confer humanity rests exclusively with the privileged and powerful. ${ }^{107}$ Instead, Humanize Palestine directly challenges the authority of the Western media to regulate who is grievable by appropriating the right to determine that Gazan lives matter. In the process, it subverts and resignifies public naming as a mode of humanisation, opening it up to possibilities foreclosed within the order of grievability in contention.

Finally, and relatedly, the assertion of humanity enacted by Humanize Palestine is undertaken by the ungrievable themselves, by those formerly assumed to be constitutively excluded from the category of the human. This is part of its radicality. As noted above, the litigious name of the 'human', provisionally and contingently appropriated in conditions of inequality, incites the appearance of (new) resistant political subjects. ${ }^{108}$ Organised and sourced by Palestinians, Humanize Palestine therefore serves as one medium through which Palestinians are able to 'speak for themselves', ${ }^{109}$ to 'make themselves of some account' politically. ${ }^{110}$ It is a means through which they performatively enact their grievability and demonstrate that they are persons whose lives count. Expressed differently, through these activities the not-yet-human propel themselves into public view as meaningfully human.

\section{Conclusion}

The emphasis in this article has been on the events in Gaza in 2014. But, of course, the initiatives explored here are far from the only ones currently seeking to assert grievability for the ungrievable.

106 See Rancière, 'Politics, identification, and subjectivization', p. 62.

107 This is not to claim, however, that there is never any value, tactical or pragmatic, either in seeking recognition within existing norms or from the powerful. Sometimes these may be the only options. My point is simply that actions by subaltern groups in performatively enacting their own humanity are more are likely to produce, what Anne Phillips calls, 'a jolt to the system', able to denaturalize and unsettle existing hierarchies, than when humanity is conferred on them by others. See Anne Phillips, The Politics of the Human (Cambridge: Cambridge University Press, 2015), p. 75.

108 See also Schaap, 'Enacting the right to have rights', p. 36.

109 Humanize Palestine, 'Why We Chose'.

${ }^{110}$ Rancière, Disagreement, p. 27, emphasis added. It is worth noting that Humanize Palestine operates in English not Arabic. This might be understood as one of the ways in which it internationalises its struggle. 
To give a handful of examples: in the summer of 2013 the hashtag \#BlackLivesMatter began to appear on social media, marking the start of a campaign highlighting police violence against African Americans. ${ }^{111}$ This was followed in February 2015 by the campaign, \#SayHerName, focusing on the plight of black female victims of the same violence. ${ }^{112}$ On 30 April 2015, a list was laid down on the floor of the European Parliament naming all the 'migrants' drowned in the Mediterranean. ${ }^{113}$ And, finally, launched in September 2013 by the London-based Bureau of Investigative Journalism, the project 'Naming the Dead' records and publishes the names of all those killed in US drone strikes in Pakistan. ${ }^{114}$ Like Humanize Palestine, some of these interventions explicitly deploy the human as a litigious name, though not all do. Like Humanize Palestine some provide information about the dead as well as their names, though, again, not all do. In terms of the arguments made in this article, all of them, however, evidence the politics of the human.

There are two inter-related aspects to this politics. First, the human is a category that disallows or forecloses the inclusion of certain embodied persons within it; one that rests on the normative operations of social ontology, operations that condition who is apprehensible as fully and meaningfully human and who is not. The ontological status of being (re)cognisable as human depends, in other words, on the functioning of various social and political forces, norms, and power. Second, the human is also, and somewhat paradoxically, a category amenable to litigious invocation by subaltern groups in specific contexts; a name that allows them to stage disputes contesting their subordination, dispossession, and derealisation, disputes that - potentially, at least - make possible a reconfiguration of exclusionary definitions of ontology, grievability, and the human. ${ }^{115}$ This is why, in tracking the category of the politics of the human in this article, I have offered no substantive account of the qualities or attributes assumed to devolve to it (classically: speech, language, or rationality), made no assumptions that all humans share the same properties or characteristics differentiating them from so-called 'non-humans', or used the term to refer to humanity or the human species, per se.

Instead, my focus has been on the ways in which naming, as a historical and cultural convention, has been aligned with humanisation in a specific context, Gaza in 2014, and how, consequently, the failure to name Palestine's dead, a failure amplified in this case by their algorithmic representation, effects the latter's dehumanisation. In my analysis of this example, I have accepted prima facie the

111 The phrase 'Black Lives Matter' was originally coined by Alicia Garza in the wake of the acquittal of George Zimmerman for the killing of seventeen-year-old Trayvon Martin. The hashtag was added by her friend Patrisse Cullors, one of the other founders of Black Lives Matter with Garza and Opal Tometi. Elizabeth Day, '\#BlackLivesMatter: the birth of a new civil rights movement', The Guardian (19 July 2015).

112 The hashtag \#SayHerName was coined by the African American Policy Forum. See their document, Say Her Name: Resisting Police Brutality Against Black Women (July 2015). See also Treva B. Lindsey, 'Post-Ferguson: a "herstorical" approach to black violability', Feminist Studies, 41:1 (2015), pp. 232-9.

${ }^{113}$ An image of the list is available at $\{\mathrm{https} / /$ twitter.com/SofiaBettiza/status/5933443586696558592\}, accessed 30 April 2015. In this instance, the politics of naming the dead also extends to how the dead ought to be described: as 'migrants', 'refugees', 'asylum seekers', and so forth.

114 The website is available at: \{https://www.thebureauinvestigates.com/namingthedead/the-dead/?lang=en\}, accessed 10 July 2016.

${ }^{115}$ I am not making an a priori claim here that appropriating the language of the human will always and necessarily have such radical or positive effects for the ungrievable. Much depends on the determinate circumstances in which such an invocation occurs. There will almost certainly be times it fails, where opportunities to resignify the human are curtailed or even foreclosed. At such moments, and despite the issues outlined in this article, others may have to challenge specific practices of dehumanisation on behalf of those who are unable to do so. See Lloyd, '(Women's) human rights', p. 99. 
link posited, by those involved, between naming and humanisation, and de-nomination and dehumanisation. Whether nomination is ever really sufficient on its own to humanise the dead is moot. Arguably, enumerating long lists of names of the dead serves only to convey the sheer volume of those killed much in the way numbers do, while the routinisation of such reporting risks normalising the violent deaths of the populations involved much in the way that body counts do, such that the public come to expect and accept such killings as a matter of course. These are, however, issues for another time.

What seems clear, as I have demonstrated in this article, is that when a particular population is constituted as ungrievable, when its members are not apprehensible as ontologically human within a specific order of grievability, as in the case of Palestinians in respect of the Western media, then naming them publically is an act of political dissent. When the ungrievable undertake this task themselves, as in the example of Humanize Palestine, when they claim grievability for themselves, rather than have others do it on their behalf, their actions implement - performatively enact - the equality invoked by the human as a litigious name. Asserting their humanity thus is the way they establish that their lives do indeed count.

\section{Acknowledgements}

Earlier versions of this article were delivered at the University of Cambridge Seminar for Contemporary Political Thought and as part of the University of Kent Public Lecture Series at the Brussels School of International Studies. I would like to thank both audiences for their very helpful comments and questions. I would also like to thank Andrew Thacker for reading this article in its various iterations, as well as the anonymous reviewers of the Review of International Studies for providing such incisive, extremely thorough, and careful comments. A Leverhulme Trust Major Research Fellowship funded the research project from which this article arises.

\section{Biographical information}

Moya Lloyd is Professor of Political Theory at Loughborough University. She has published extensively in the areas of contemporary social and political theory, and feminist and gender theory, particularly on the work of Judith Butler. Her most recent book is the edited volume Butler and Ethics (Edinburgh University Press, 2015). From 2013-16 she was holder of a Leverhulme Major Research Fellowship, for the project: 'Who counts? The political problem of the "human"'. 